\title{
PENGARUH JENIS ELEKTRODA DAN JUMLAH PASS TERHADAP UJI KEKERASAN HASIL PENGELASAN DAN STRUKTUR MIKRO PADA PROSES PENGELASAN SHIELDED METAL ARCH WELDING
}

\author{
${ }^{1}$ Yeni Ratih Pratiwi \\ ${ }^{2}$ Salnan Sabdo Wibowo
}

${ }^{1,2}$ Dosen Teknik Mesin, Universitas Nahdlatul Ulama Blitar

Email : ${ }^{1}$ yeniratihpratiwi@yahoo.com, ${ }^{2}$ salnan.salnan@gmail.com

\section{Tersedia Online di \\ http://www.jurnal.unublitar.ac.id/ index.php/briliant}

\section{Sejarah Artikel}

Diterima pada 15 April 2019

Disetuji pada 24 April 2019

Dipublikasikan pada 22 Mei 2019

Hal. 159-166

\section{Kata Kunci:}

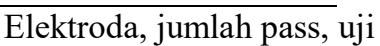

kekerasan, struktur mikro, pengelasan SMAW

\section{DOI:}

http://dx.doi.org/10.28926/briliant .v3i4.287

Abstrak: Proses pengelasan Shielded Metal Arc Welding banyak digunakan dalam dunia industri untuk proses pengelasan logam. Penggunaan $S M A W$ dengan jenis elektroda dan jumlah pass yang tidak tepat akan menghasilkan bentuk geometri yang memiliki tingkat kepresisian yang rendah dan kekasaran permukaan yang tinggi dalam proses pembuatan benda kerja. Pergerakan dan jenis elektroda las dapat mempengaruhi karakteristik hasil lasan, pada sisi lain jenis dan bentuk gerakan elektroda untuk pengelasan sering menjadi pilihan pribadi dari tukang las itu sendiri tanpa memperhatikan kekuatan lasnya. Pengerjaan las yang salah bisa mengakibatkan kerusakan pada hasil pengelasan yang berakibat fatal baik dilihat dari sisi keselamatan dan ekonomis. Penelitian ini akan dilakukan untuk menentukan pengaruh elektroda dan jumlah pass terhadap uji kekerasan hasil pengelasan dan struktur mikro pada proses pengelasan Shielded Metal Arc Welding. Plat yang dipakai dalam penelitian ini adalah plat berbentuk persegi panjang dengan tebal $10 \mathrm{~mm}$ panjang $30 \mathrm{~mm}$ dan lebar $15 \mathrm{~mm}$. Plat tersebut akan dilas dan akan dianalisis perbedaan tingkat kekerasannya akibat dari proses pelekatan elektroda dan jumlah pass. Spesimen pertama yang diamati adalah plat yang dilas menggunakan elektroda E6013 dengan jumlah pass 3 layer 3 pass. Spesimen kedua yang diamati adalah plat yang dilas menggunakan elektroda E6013 dengan jumlah pass 3 layer 6 pass. Spesimen ketiga yang diamati adalah plat yang dilas menggunakan elektroda E7016 dengan jumlah pass 3 layer 3 pass. Spesimen keempat yang diamati adalah plat yang dilas menggunakan elektroda E7016 dengan jumlah pass 3 layer 6 pass. Masing masing dilakukan pengulangan sebanyak $3 \mathrm{x}$.

\section{PENDAHULUAN}

Pengelasan adalah proses penyambungan antara dua buah logam dengan menggunakan energi panas, sehingga logam las dan logam yang berada disekitar daerah las mengalami perubahan struktur metalurgi, deformasi dan tegangan termal. Definisi pengelasan menurut DIN (Deutsche Industrie Norman) adalah ikatan metalurgi pada sambungan logam atau logam paduan yang dilaksanakan dalam keadaan lumer atau cair. Sedangkan menurut Welding Handbook, proses pengelasan adalah penyambungan bahan yang menghasilkan peleburan bahan dengan memanasinya hingga suhu yang tepat dengan atau tanpa pemberian tekanan dan dengan atau tanpa pemakaian bahan pengisi. Dengan kata lain, las merupakan sambungan setempat dari beberapa batang logam dengan menggunakan energi panas. Untuk mengurangi pengaruh buruk tersebut, maka dalam proses pengelasan perlu prosedur pengelasan yang benar dan tepat dengan 
mencari nilai dari parameter pengelasan yang optimal. Pengelasan dengan proses Shielded Metal Arc Welding (SMAW) merupakan salah satu jenis proses pengelasan dengan busur listrik, dimana panas didapat dari busur nyala yang memancar antara elektroda dengan flux dan benda kerja. Dunia Industri banyak menggunakan jenis proses pengelasan SMAW disamping jenis proses Pengelasan Gas Metal Arc Welding (GMAW), Gas Tungsten Arc Welding ( GTAW), Submerged Arc Welding (SAW) dan frisktion Welding. Ciri utama dari proses pengelasan SMAW adalah pada jenis electrode yang digunakan yang menggunakan jenis elektroda yang terbungkus dengan fluks.

Elektroda pada proses pengelasan SMAW terdiri dari dua bagian yaitu, inti elektroda dan fluks (selaput). Inti elektroda berfungsi sebagai penghantar arus listrik dan menjadi deposit las. Fungsi fluks pada elektroda berfungsi untuk memproduksi gas pelindung pada saat proses pengelasan dan menjadi slag (terak) setelah proses pengelasan. Adapun salutan (flux) ini terdiri dari campuran bahan mineral dan zat kimia dan inilah yang menentukan karakter pengoperasian dan komposisi pada akhir pengelasan. Jenis elektroda yang diklasifikasikan menurut standar pengkodean tertentu. Menurut American Welding Society (AWS) jenis elektroda SMAW dinyatakan dengan tanda E diikuti 4 digit angka, seperti E 6013 dan E 7016. Huruf E artinya Elektroda SMAW. Dua angka pertama artinya kekuatan tarik minimum dalam Psi. angka ketiga menunjukkan posisi pengelasan yang dapat dilaksanakan dan angka terakhir menunjukkan jenis polaritas dan jenis selaput. Beberapa Jenis elektroda yang sering dipakai pada proses pengelasan SMAW: E 6013, E 7016. Proses pengelasan bisa dilakukan pada beberapa posisi. Klasifikasi posisi pengelasan bisa didasarkan pada standar AWS, ASMI, ISO atau BKI. Khusus jenis posisi pengelasan plat dengan plat menurut AWS diklasifikasikan menjadi delapan, yaitu: 1F, 2F, 3F, 4F, 1G, 2G, 3G, 4G. Pada proses pengelasan $1 \mathrm{G}$ dengan kampuh $\mathrm{V}$ terdapat 2 cara dalam melaksanakan proses pengelasannya, yaitu dengan 3 layer 3 pass dan 3 layer 7 pass. Pada proses pengelasan dengan 3 layer 3 pass, gerakan elektroda diayun sedangkan 3 layer 6 pass, gerakan elektroda lurus saja. Pergerakan dan jenis elektroda las dapat mempengaruhi karakteristik hasil lasan, pada sisi lain jenis dan bentuk gerakan elektroda untuk pengelasan sering menjadi pilihan pribadi dari tukang las itu sendiri tanpa memperhatikan kekuatan lasnya. Pengerjaan las yang salah bisa mengakibatkan kerusakan pada hasil pengelasan yang berakibat fatal baik dilihat dari sisi keselamatan dan ekonomis.

Baja adalah paduan besi dengan kandungan karbon sampai maksimum sekitar 1,5\% . Paduan besi dengan karbon di atas 1,5\% disebut dengan besi cor. Kegunaan baja sangat bergantung dari pada sifat - sifat baja yang sangat bervariasi yang diperoleh dari pemaduan dan penerapan proses perlakuan panas. Sifat mekanik dari baja sangat bergantung pada struktur mikronya. Sedangkan struktur mikro sangat mudah dirubah melalui proses perlakuan panas. Logam baja sudah digunakan secara luas di dunia industry seperti untuk plat, baja profil, mur dan baut yang kesemuanya sering menggunakan proses pengelasan didalamnya. Parameter dalam pengelasan bisa mempengaruhi struktur mikro dalam logam yang dilas sehingga mampu mempengaruhi sifat mekanik dari loam hasil pengelasan. Salah satu sifat mekanik yang paling penting dalam pengelasan adalah sifat kekerasan (hardness). Melihat berbagai pilihan jenis elektroda dan

160 BRILIANT: Jurnal Riset dan Konseptual Volume 4 Nomor 2, Mei 2019 
jumlah pass diatas, melatar belakangi penelitian ini untuk mengetahui pengaruh jenis elektroda dan jumlah pass pada struktur mikro dan kekerasan logam.

\section{METODE}

Pendekatan yang digunakan dalam penelitian ini adalah pendekatan analisis deskriptif. Berikut menunjukkan diagram alir dari penelitian yang dilakukan.

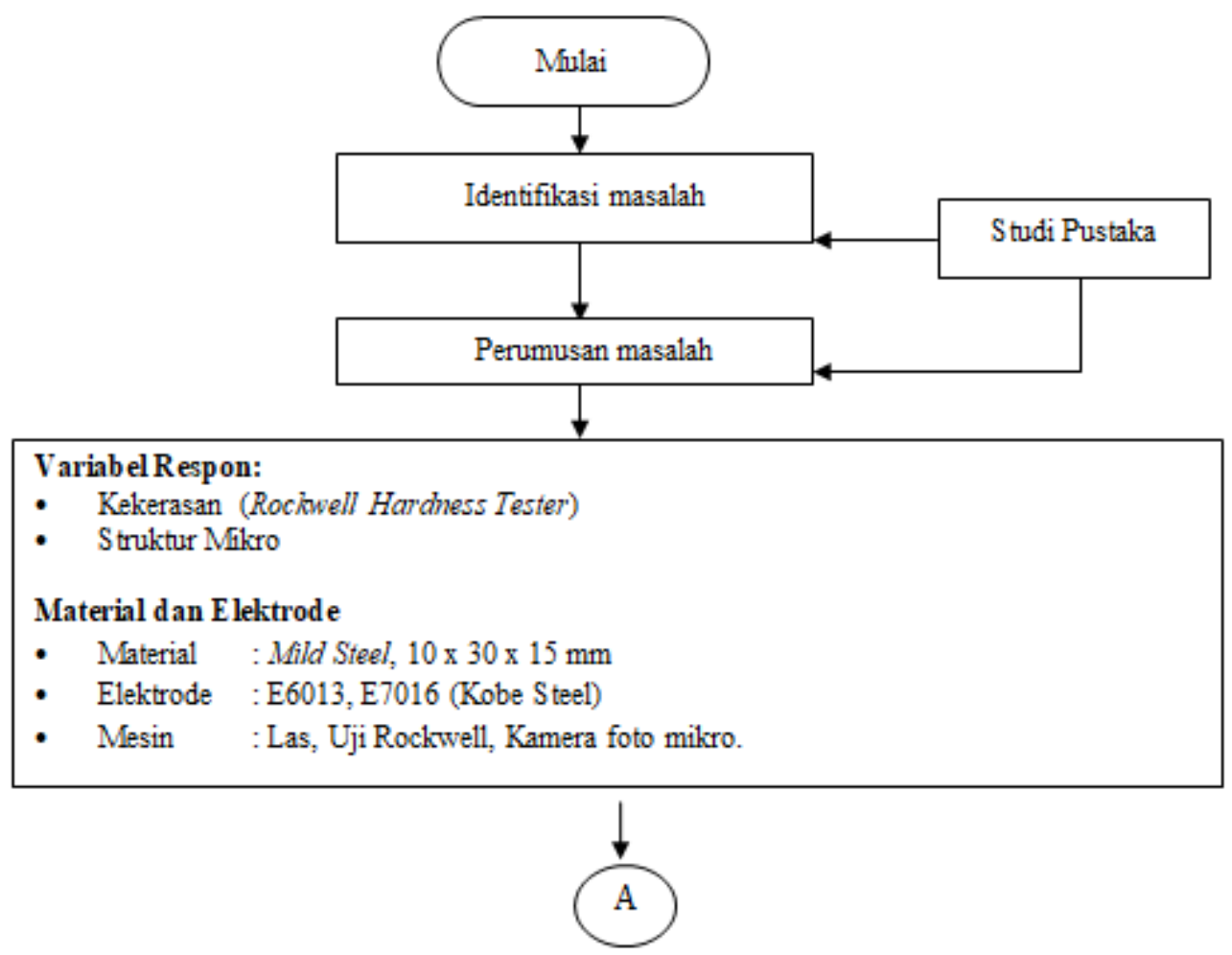

Gambar 1 diagram alir tahapan penelitian

Langkah-langkah yang diambil dari penelitian ini dimulai dari persiapan peralatan dan bahan, kemudian dilanjutkan dengan pengambilan data. Dimana untuk pengambilan data dimulai dari pemotongan bahan, pembentukan spesimen dengan cara dilas, kemudian diuji kekerasan dan struktur mikro nya berdasarkan jenis elektroda dan jumlah pass yang berbeda. Plat yang dipakai dalam penelitian ini adalah plat berbentuk persegi panjang. Spesimen plat ini memiliki ukuran pada setiap specimen dengan tebal $10 \mathrm{~mm}$ panjang $30 \mathrm{~mm}$ dan lebar $15 \mathrm{~mm}$. Total semua specimen yang nantinya akan dilas 16 spesimen dengan bentuk dan ukuran yang sama. Plat tersebut akan dilas dan akan dianalisis perbedaan tingkat kekerasannya akibat dari proses pelekatan elektroda dan jumlah pass. Spesimen pertama yang diamati adalah plat yang dilas menggunakan elektroda E6013 dengan jumlah pass 3 layer 3 pass. Spesimen kedua yang diamati adalah plat yang dilas menggunakan elektroda E6013 dengan jumlah pass 3 layer 6 pass. Spesimen ketiga yang diamati adalah plat yang dilas menggunakan elektroda E7016 dengan jumlah pass 3 layer 3 pass. Spesimen keempat yang diamati adalah plat yang dilas menggunakan elektroda E7016 dengan jumlah pass 3 layer 6 pass. Masing masing dilakukan pengulangan sebanyak 3x.

Dari data yang diperoleh selanjutnya akan dianalisis. Teknik analisis data yang digunakan dalam penelitian ini adalah analisis deskriptif, yaitu untuk 
mengetahui rata-rata dari masing-masing percobaan proses pengelasan SMAW pada plat dengan variasi jenis elektroda dan jumlah pass yang berbeda-beda.

\section{HASIL}

Data yang dihasilkan dalam penelitian ini berupa angka dan pemaparan yang meliputi pengujian kekerasan Rockwell Hardness Tester pada material baja ST 42 yang telah mengalami proses pengelasan dengan variasi jenis elektroda dan jumlah pass. Adapun jenis plat yang digunakan adalah baja jenis mild steel atau baja karbon rendah, dengan elektroda yang dipakai adalah jenis E6013 dan E7016. Jumlah pass yang digunakan adalah 3 layer 3 pass dan 3 layer 6 pass.

Uji kekerasan ini dilakukan di Laboratorium Pengujian Material Institut Teknologi Nasional Malang. Pengujian kekerasan menggunakan mesin Brevetti $A F F R I$ pada tiga titik yang berbeda untuk setiap spesimen. Hasil pengujian berupa angka. Adapun hasil pengujian kekerasan baja mild steel sebagai berikut:

Tabel 1 Hasil Uji Kekerasan Menggunakan Variasi Jenis Elektroda dan Jumlah Pass

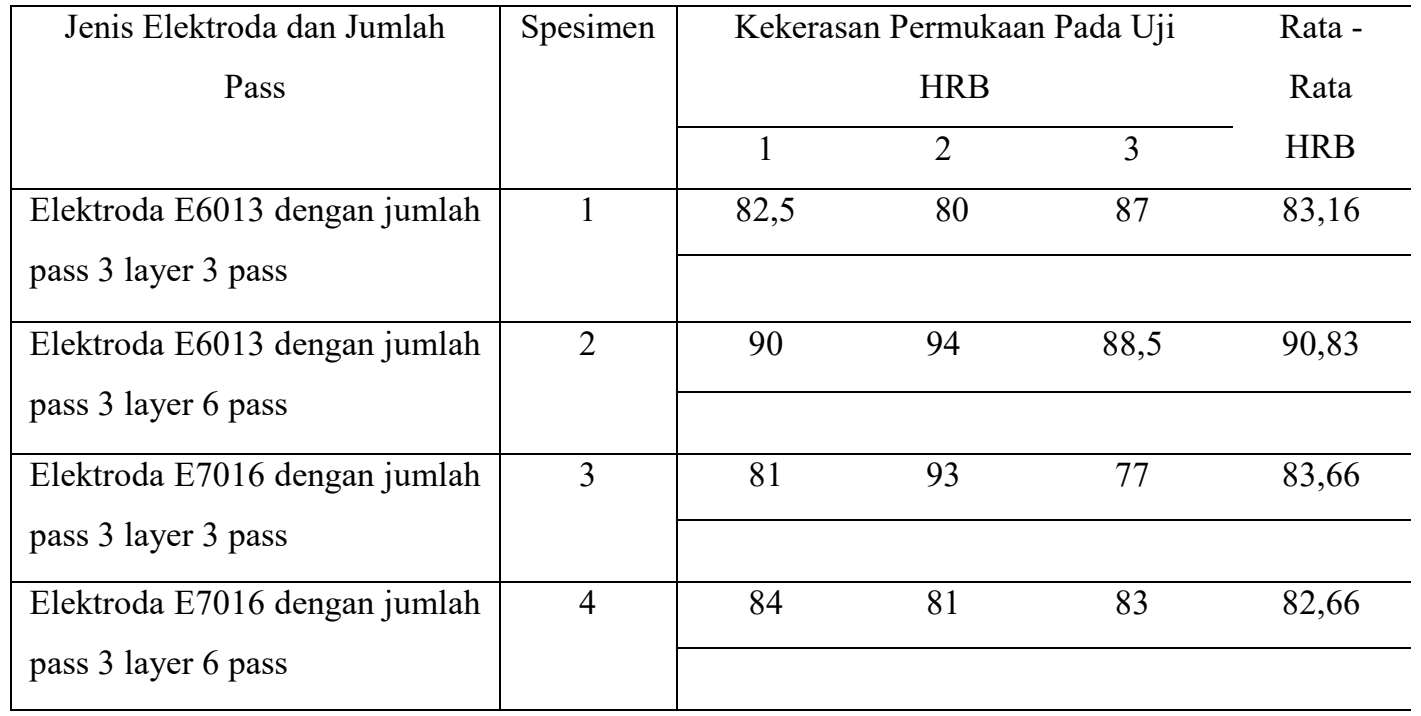

Dari tabel 1 dapat dilihat hasil pengujian kekerasan Rockwell Hardness Tester memiliki angka kekerasan terendah 82,66 HRB dan angka kekerasan tertinggi sebesar 90,83 HRB. Angka kekerasan rata-rata untuk spesimen 1 adalah 83,16 HRB. Angka kekerasan rata-rata untuk spesimen 2 menunjukkan nilai 90,83 HRB. Angka kekerasan rata-rata untuk spesimen 3 adalah 83,66 HRB. Angka kekerasan rata-rata untuk spesimen 4 adalah 82,66 HRB. Sehingga angka rata-rata untuk tingkat kekerasan keempat spesimen pada baja ST 42 setelah mengalami proses variasi pengelasan SMAW dengan elektroda E6013 dan E7016 dengan jumlah pass 3 layer 3 pass dan jumlah pass 3 layer 6 pass dalam skala HRB menunjukkan angka rata-rata 85,07 HRB.

Dari semua specimen yang telah diuji didapatkan hasil untuk specimen yang memiliki nilai kekerasan paling besar adalah specimen yang dilas menggunakan elektroda E6013 dengan jumlah pass 3 layer 6 pass.

Grafik hasil pengujian kekerasan dapat dilihat pada gambar 2 dibawah ini: 


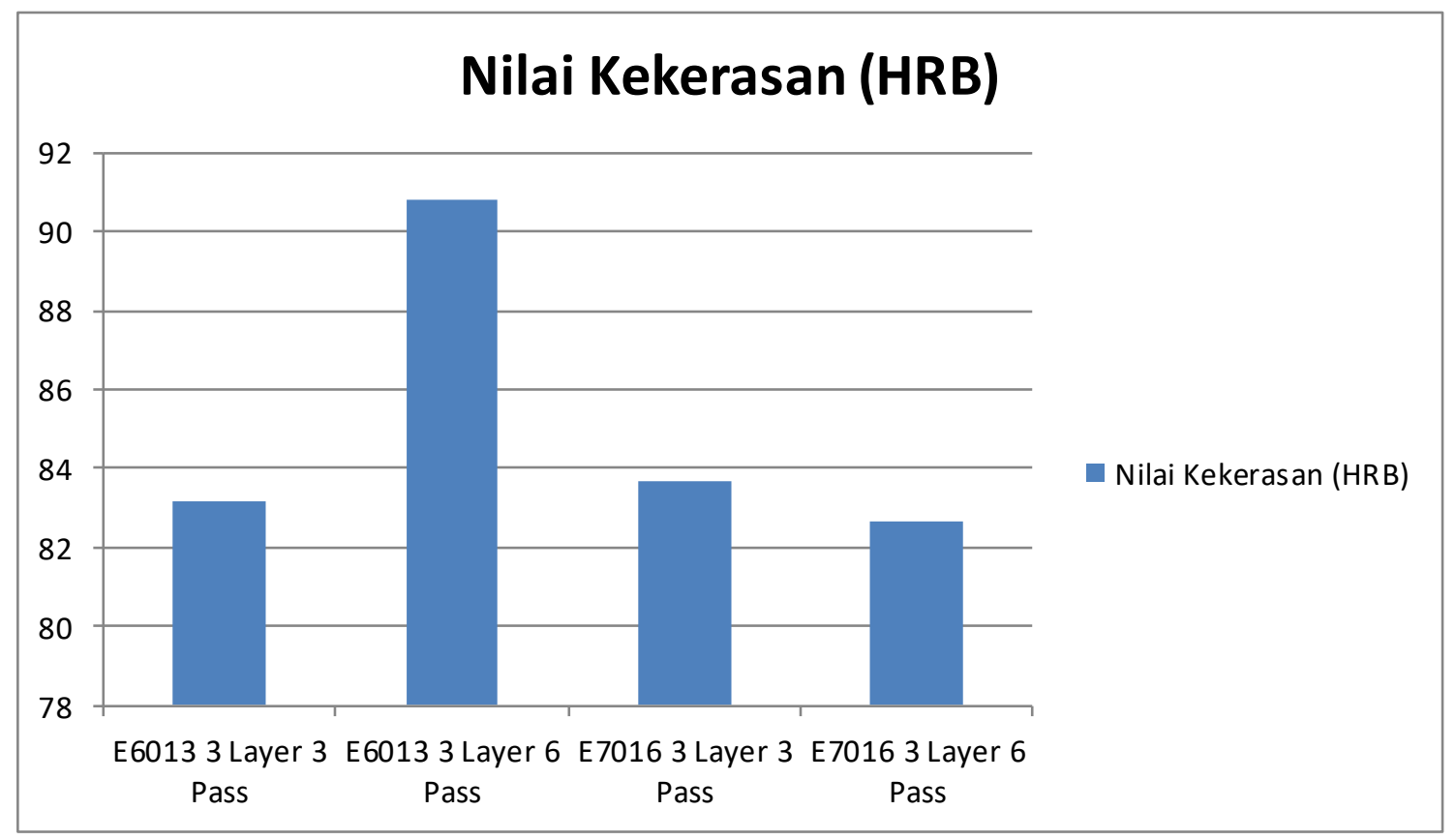

Struktur mikro adalah gambaran dari kumpulan fasa-fasa yang dapat diamati melalui teknik metalografi. Struktur yang dimiliki oleh baja karbon rendah didominasi oleh ferit dan perlit. Pengujian struktur mikro menggunakan Micro Hardeness Tester dengan pembesaran foto diperoleh dari perkalian lensa objektif dan okuler lensa obyektif yang dipakai 50x, lensa okuler 10x sehingga pembesaran bisa mencapai 500x. Foto mikro yang diambil yaitu pada daerah HAZ (Heat Affected Zone). Adapun foto mikro specimen baja ST 42 sebagai berikut: Hasil foto mikro specimen E7016, 3 Layer 3 Pass dapat dilihat pada gambar 3 di bawah ini:

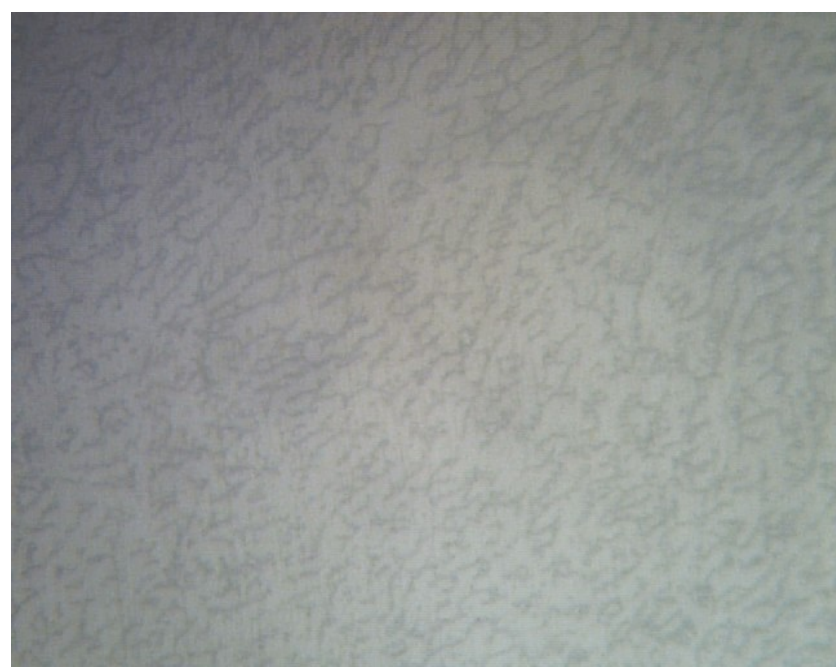

Hasil Foto Mikro Spesimen E7016, 3 Layer 6 pass bisa dilihat pada gambar 4 dibawah ini 


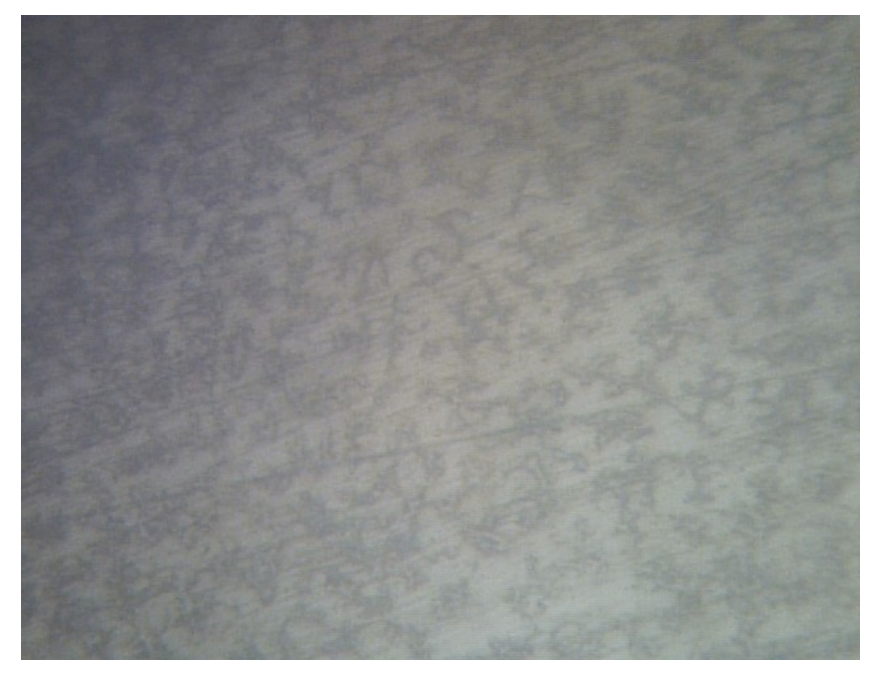

Hasil Foto Mikro Spesimen E6013, 3 Layer 3 pass bisa dilihat pada gambar 5 di bawah ini

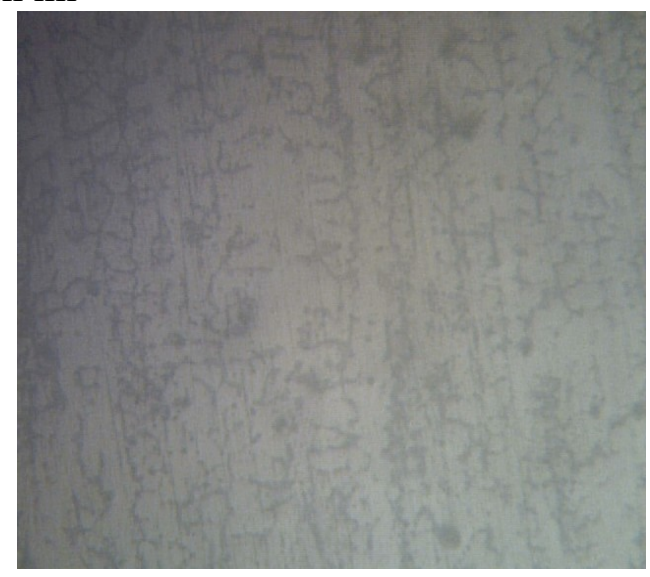

Hasil Foto Mikro Spesimen E6013, 3 Layer 6 Pass bisa dilihat pada gambar 6 di bawah ini

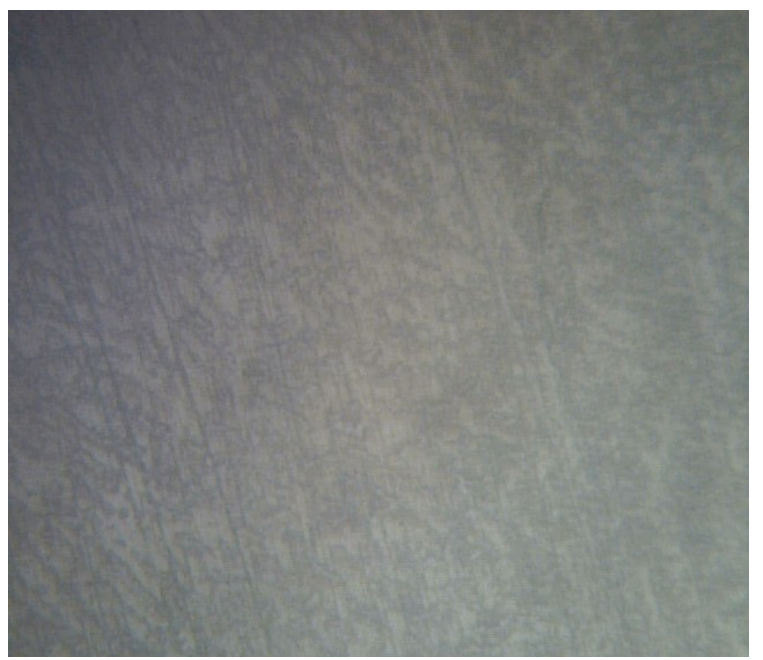

164 BRILIANT: Jurnal Riset dan Konseptual

Volume 4 Nomor 2, Mei 2019 
Spesimen ini dilas menggunakan spesimen dari elektroda E7016, struktur mikro yang terjadi pada ferit (terang), perlit (gelap) yang bila dibandingkan dengan logam dasar, lebih halus dengan jumlah yang lebih sedikit daripada lasan lainnya. Struktur mikro pada gambar di atas adalah area HAZ, struktur mikro dalam gambar didominasi oleh butir ferit putih terang, sedangkan fase perlit lebih gelap. Butir ferit cenderung lebih halus sementara butiran perlit lebih kasar, biji perlit cenderung keras karena mengandung karbon, sedangkan butiran ferit cenderung lunak.

Untuk hasil mikro, dapat dijelaskan bahwa HAZ dari logam dasar selama proses pengelasan di bawah siklus termal. Setelah pemanasan proses besi-gamma atau austenit mulai berubah menjadi besi-alfa atau ferit dimana ferit memiliki kelarutan karbon yang sangat sedikit untuk menetap terus menerus sepanjang batas butir austenit. Kemudian austenit akan berubah menjadi perlit dan berakhir pada suhu sekitar $500^{\circ} \mathrm{C}$. Di bawah suhu $500^{\circ} \mathrm{C}$ austenit akan berubah menjadi bainit dan berakhir pada suhu $300^{\circ} \mathrm{C}$, kemudian pada suhu di bawah $300^{\circ} \mathrm{C}$ austenit yang tersisa akan menjadi martensit. Jadi struktur akhir yang diperkirakan terbentuk adalah ferit perlite. Struktur ini memiliki kekerasan yang cukup baik, kemudian dengan meningkatnya persentase perlit dari kandungan ferit karena meningkatnya jumlah lapisan akan meningkatkan kekerasan suatu material.

Hasil yang diperoleh dari uji kekerasan serta struktur mikro menunjukkan bahwa jenis elektroda dan jumlah pass secara signifikan mempengaruhi sifat mekanik dan struktur mikro baja. Ini menunjukkan dengan meningkatnya jumlah lapisan, struktur mikro yang terbentuk memiliki banyak konten perlit, yang berarti semakin keras. Struktur yang terjadi pada sambungan las sangat ditentukan oleh komposisi kimia, logam dasar, logam pengisi, metode pengelasan dan perlakuan panas yang dilakukan. Jenis elektroda dan jumlah lintasan menyebabkan mikro yang berbeda di wilayah HAZ. Di daerah HAZ untuk elektroda E6013 dan E7016 keduanya mengandung ferit dan perlite. Namun untuk spesimen E6013 dengan jumlah pass 3 layer 6 pass memiliki perlit paling banyak, yang berarti spesimen ini cenderung lebih keras karena mengandung karbon.

\section{KESIMPULAN}

Berdasarkan hasil penelitian dan analisa yang telah dilakukan pada baja karbon rendah disertai dengan proses pengelasan dengan variasi elektroda dan jumlah pass maka dapat diambil kesimpulan sebagai berikut:

1. Jenis elektroda yang digunakan untuk pengelasan sangat berpengaruh terhadap kekerasan dari baja yang dilas.

2. Jumlah layer dan jumlah pass yang digunakan dalam pengelasan sangat berpengaruh terhadap kekerasan dari baja hasil las.

3. Jenis elektroda dan jumlah pass sangat mempengaruhi nilai kekerasan dan struktur mikro. Jenis elektroda E6013 dengan jumlah pass 3 layer 6 pass memiliki nilai kekerasan paling tinggi dan struktur mikronya memiliki perlit paling banyak.

\section{SARAN}

Dalam proses penelitian yang dilakukan, pengelasan baja karbon rendah yang disertai dengan variasi elektroda dan jumlah pass ini dapat diberikan saran-saran sebagai berikut: 
1. Pada saat melakukan pengelasan, sebaiknya prosedur pengelasan benar-benar dilakukan dan menggunakan alat pelindung sesuai dengan standart keselamatan kerja.

2. Disarankan agar dilakukan penelitian sejenis pada variasi yang lain.

3. Untuk kajian lebih lanjut perlu dilakukan analisis hubungan antara hasil pengelasan baja dengan variasi temperatur pemanasan awal (preheated), variasi arus, variasi kampuh, variasi pendinginan, variasi ketebalan benda kerja, dan variasi kecepatan pengelasan.

\section{DAFTAR RUJUKAN}

Daryanto. 2012. Teknik Las. Bandung: Penerbit Alfabeta.

Fong Yih, Tzeng dan Chen Fu-chen. 2003. A simple approach for robust design of high-speed electrical- discharge machining technology. International Journal of Machine Tools \& Manufacture, Vol.43, hal. 217-227.

Montgomery, D. C.. 2009. Design and Analysis of Experiment. John Wiley \& Sons. Inc., New York.

Moshat, S. dkk. 2010. "Parametric Optimization of CNC End Milling using Entropy Measurement Technique Combined with Grey-Taguchi Methode," International Journal of Engineering, Science and Technology, vol. 2, No. 2, hal.1-12.

Rochim, T. 2001. Proses Pemesinan. Bandung: Institut Teknologi Bandung.

Roger timings, 2008. Fabrication and welding engineering. Elsevier Ltd: Burlington.

Soejanto, I. 2009. Desain Eksperimen dengan Metode anova. Yogyakarta: Graha Ilmu.

Tarkono, Sugiyanto, Andriyanto, 2010. Studi Kekuatan Sambungan Las Baja AISI 1045 dengan Berbagai Metode Posisi Pengelasan. Lampung: Universitas Lampung.

The ABC's Of Arc Welding and Inspection, 2015, kobesteel Ltd, Tokyo.

Welding Handbook, 1976. Material and Application, eight edition, volume IV, Florida: American Welding Society.

Wiryosumarto, H. Toshie, O. 2004. Teknologi Pengelasan Logam. Jakarta: Pradnya Paramitha (Cetakan ke-9). 